\title{
Chemical Fingerprint and Anti-Sickling Activity of Rosmarinic Acid and Methanolic Extracts from Three Species of Ocimum from DR Congo
}

\author{
Dorothée D. Tshilanda1, Paulin K. Mutwale², Damase V. N. Onyamboko, \\ Philippe B. Babady ${ }^{3}$, Philippe V. Tsalu1, Damien S. T. Tshibangu', Nadege K. Ngombe², \\ M. Frederich ${ }^{4}$, Koto-te-Nyiwa Ngbolua ${ }^{5}$, Pius T. Mpiana ${ }^{1^{*}}$ \\ ${ }^{1}$ Department of Chemistry, Faculty of Science, University of Kinshasa, Kinshasa, Democratic Republic of the \\ Congo \\ ${ }^{2}$ Centre d'Etudes des Substances Naturelles d'Origine Végétale (CESNOV), Faculty of Pharmaceutical Sciences, \\ University of Kinshasa, Kinshasa, Democratic Republic of the Congo \\ ${ }^{3}$ Bila Nutraceuticals Company, Dartmouth, Canada \\ ${ }^{4}$ Laboratory of Pharmacognosy, Department of Pharmacy, CIRM, University of Liège, CHU, Liège, Belgium \\ ${ }^{5}$ Department of Biology, Faculty of Science, University of Kinshasa, Kinshasa, Democratic Republic of the Congo \\ Email: "ptmpiana@yahoo.fr
}

Received 31 October 2015; accepted 11 January 2016; published 14 January 2016

Copyright (C) 2016 by authors and Scientific Research Publishing Inc.

This work is licensed under the Creative Commons Attribution International License (CC BY).

http://creativecommons.org/licenses/by/4.0/

(c) (i) Open Access

\section{Abstract}

The aim of this study was to characterize the polyphenolic composition by determination of chemical fingerprints of Methanolic extracts of Ocimum canum Sims, Ocimum basilicum L. and Ocimum gratissimum L. from Democratic Republic of Congo and to compare their antisickling activity of that of rosmarinic acid, the major compound to those of methanolic extracts. Phytochemical analysis performed by TLC and HPLC analysis, showed that rosmarinic acid is the most abundant phenolic acid in these Ocimum species according to the following order $O$. basilicum L., 0 . gratissimum L. and 0 . canum Sims. Methanolic extracts of these three species and pure rosmarinic acid showed significant antisickling activities with minimal concentration of normalization values of $0.18 \pm$ $0.03,0.23 \pm 0.04,0.26 \pm 0.04$ and $0.31 \pm 0.05 \mathrm{mg} / \mathrm{mL}$ for rosmarinic acid, 0 . basilicum L., 0 . gratissimum L. and 0 . canum Sims methanolic extracts respectively. The antisickling activity order is the same as that of the rosmarinic acid content, indicating that this polyphenolic acid would be among the main active molecules in these extracts.

"Corresponding author.

How to cite this paper: Tshilanda, D.D., et al. (2016) Chemical Fingerprint and Anti-Sickling Activity of Rosmarinic Acid and Methanolic Extracts from Three Species of Ocimum from DR Congo. Journal of Biosciences and Medicines, 4, 59-68.

http://dx.doi.org/10.4236/jbm.2016.41008 
Keywords

Antisickling, Chemical Fingerprint, O. canum, O. basilicum, O.gratissimum, Rosmarinic Acid

\section{Introduction}

Sickle cell disease (SCD) or sickle anemia is a hereditary blood disorder due to an abnormal hemoglobin, hemoglobin S (HbS). In low oxygen pressure condition, HbS aggregate into intracellular polymers, that confer the shape called sickle form to erythrocytes. This Red blood cells (RBCs) shape modification makes them fragile and less flexible; what causes many complications of sicklers [1] [2].

This chronic disease affects mainly sub-Saharan African. In Democratic Republic of the Congo (RDC) more than one and half millions of people are affected [3]-[5].

Some proposed therapeutic options seem inappropriate for low-income countries population, mainly in Africa. The World Health Organization (WHO) reported that $80 \%$ of the African population relies on herbal medicine for therapy. The extensive use of herbal medicine in Africa, has been argued to be linked to cultural and economic reasons. This is why the WHO encourages African member states to promote and integrate traditional medical practices in their health system [6].

Surveys undertaken by our research team in DRC conducted to more than 115 medicinal plants used in Congolese traditional medicine to manage sickle cell disease among which was $O$. basilicum [5] [7]-[15]. In fact, in our previous works, our research team has shown that $O$. basilicum like some of medicinal plants used in Congolese herbal medicine in the management of sickle cell disease have antisickling activity in vitro. This biological activity is mainly displayed by polar fractions among which methanolic one and anthocyanins, organic acids and their derivatives were among the active chemical groups [3]-[5] [12]-[20]. O. canum and O. gratissimum, two other species of Ocimum genus found in DRC, even if they are not cited by traditional healers in the management of sickle disease, showed also in vitro antisickling activity. This, confirming similar results already obtain for some species of Justicia and Zanthoxylum (Fagara) genera [11] [21].

$O$. basilicum L., O. canum Sims and O. gratissimum L. are aromatic herbs which are used extensively to add a distinctive aroma and flavor to food. The leaves can be used fresh or dried when they are used as spice. These aromatic herbs have been used as medicinal plants in the treatment of several sickness [22]-[25].

Generally, the aromatic plants and spices of the Lamiaceae family, among which Ocimum species are rich in polyphenolic compounds and a large number of them are well known for medicinal properties [26]-[28].

Recently, our research team have tested antioxidant activity of different extracts from the three species and showed that methanolic extracts exhibited the highest activity [17] [19] [20]. Furthermore, ursolic acid isolated from O. gratissimum [18] and butyl stearate isolated from O. basilicum leaves [17] showed antisickling activity in vitro.

The aim of this work was to analyze the chemical fingerprints of the methanolic extracts of the three quoted species of Ocimum from RDC, to correlate their antisickling activity for a better characterization and understanding of the three methanolic extracts activities. And, to screen the presence of rosmarinic acid (RA), a naturally occurring phenylpropanoid known for its antioxidant and anti-inflammatory activity [29]-[31] in the extracts and to test the antisckling activity of a pure RA.

\section{Materials and Methods}

\subsection{Plant Material}

Leaves of Ocimum species were collected in the vicinity of Mbuji-Mayi (O. canum) and of the University of Kinshasa (O. basilicum and O. gratissimum) in DRC on May 2013. The collected plants were identified by comparison with reference specimen available at Biology department of University of Kinshasa, DRC. Voucher specimens (Ocimum basilicum: 425/Devred, Ocimum canum: 686/A. Thieband, Ocimum gratissimum: 8016/R. Dechamps) were deposited at the herbarium of the same department. Leaves of plants were dried at the room temperature and finely grounded in a high speed mill (Retsch ZM 100 Model) to 0.02 inches size. The powder leaves were stored in the dark at the room temperature and used for solvent extraction. 


\subsection{Biological Material}

The blood samples used for the bioassays in this study were taken from adolescent sickle cell disease patients attending the "Centre de Medicine Mixteet d'Anemie SS" (CMMASS), located in Kinshasa, DRC. A written consent for each patient was approved by the national ethic committee ( $\mathrm{N}^{\circ}$ BE117). Ethical clearance on the use of SS blood was strictly observed according to international rules [32].

In order to confirm their SS nature, the above mentioned blood samples were first characterized by hemoglobin electrophoresis on cellulose acetate gel at $\mathrm{pH} 8.5$ and then stored at $4^{\circ} \mathrm{C}$ in a refrigerator.

\subsection{Biological Assays}

Emmel's tests were performed as previously reported [3]-[5] [7] [10] [13]. The red blood cells digitized micrographs were treated with a computer assisted image analysis system (Motic Images 2000, version 1.3), Statistical analysis and curves were processed using Microcal Origin 8.6 package Software. All anti-sickling experiments were carried out in triplicate using a sodium citrate suspension of freshly collected blood as previously reported [3] [5] [13] [14] [16].

\subsection{Chemicals}

All solvents were of analytical grade and purchased from Merck VWR (Leuven, Belgium).

Rosmarinic acid, luteolin, vitexin were HPLC grade from Sigma Aldrich. Water was treated in a Milli-Q water ultra-purification system (Easy Pure Purification System).

\subsection{Preparation of Samples}

The samples were extracted from $1 \mathrm{~g}$ plant powder sonicated for $15 \mathrm{~min}$ in $10 \mathrm{~mL}$ methanol and filtered on a what man filter paper. One milligram of RA of HPLC analytical grade was dissolved in $10 \mathrm{~mL}$ methanol and gently shaken.

\subsection{Thin Layer Chromatography Analysis}

Analytical thin layer chromatography (TLC) of $10 \mu \mathrm{L}$ of solution was carried out on Silica gel $60 \mathrm{~F}_{254}$ plates (Merck), using ethyl acetate/formic acid/glacial acetic acid/water (100:11:11:26) and methylene Dichloride/ acetone/formic acid (85:25:8.5) as eluents. Luteolin, vitexin, rosmarinic acid were used as standards. The plate was sprayed with Natural Products-PEG reagent and observed at UV-365 nm.

\subsection{High Performance Liquid Chromatography Analysis}

The High performance liquid chromatography (HPLC) analysis was carried out at $25^{\circ} \mathrm{C}$ by an "Agilent 1100 " HPLC chain connected to a diode array detector (DAD). All samples and standards were filtered through a 0.45 $\mu \mathrm{m}$ pore size syringe-driven filter before $20 \mu \mathrm{L}$ of each one were injected into the HPLC-UV/DAD system. The separation was carried out using an Hypersil ODS column $(4 \mathrm{~mm} \times 250 \mathrm{~mm})$ with a nonlinear gradient of acetonitrile (solvent $\mathrm{A}$ ) and $0.05 \%$ trifluoroacetic acid in ultra-pure water (solvent $\mathrm{B}$ ) in the following composition: T0: 0\% A, 100\% B; T1: 3\% A, 97\% B; T45: 40\% A, 60\% B; T46: $0 \%$ A, 100\% B and T60 stop. The time (T) is expressed in minutes. The compounds were eluted at a flow rate of $1 \mathrm{~mL} / \mathrm{min}$ and detected with UV-DAD. The UV spectra of elution peaks were recorded in the range from 250 to $340 \mathrm{~nm}$ and the chromatograms were monitored at 280 and $340 \mathrm{~nm}$. The identification was based on the retention time and the absorption spectra in comparison to the references and the data available in the database of the system [33].

\section{Results and Discussion}

\subsection{Thin Layer Chromatography (TLC) Analysis}

Figure 1(a) and Figure 1(b) show the TLC fingerprint of methanolic extracts of the three species of Ocimum firstlyalone and then with phenols controls, respectively.

As above noticed, TLC analysis show that the different extracts of Ocimum contain polyphenols, including: Chromatogram (a): flavonoids of Kampférolkind (yellow-orange fluorescent spots) and phenolic acids (blue 

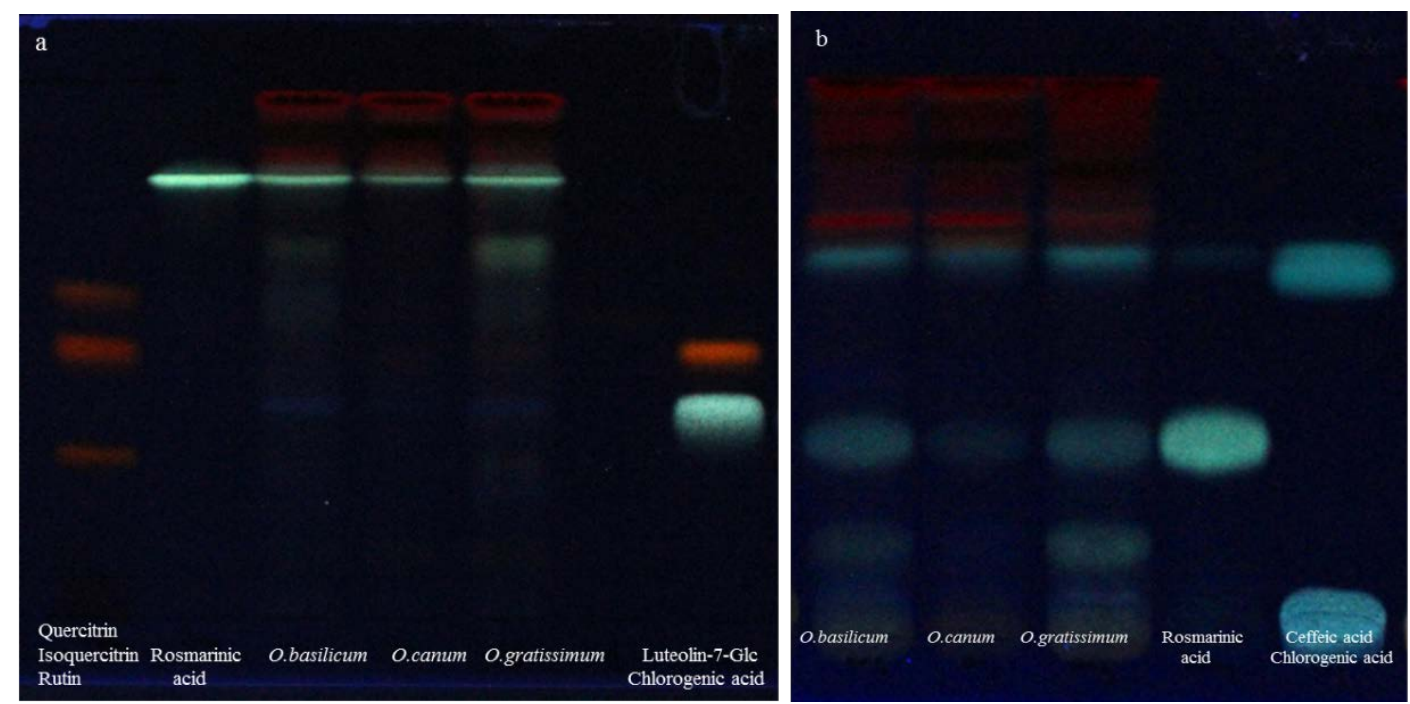

Figure 1. (a) TLC Chromatogram of methanolic extracts from O. basilicum, O. canum and O. gratissimum; developed with Ethyl acetate/formic acid/glacial acetic acid/water 100:11:11:26 and visualized at $365 \mathrm{~nm}$ with Natural Products-PEG reagent. Flavonoids are detected as yellow-orange fluorescent spot and phenolic acids as blue fluorescent spot [34]; (b) TLC Chromatogram of methanolic extracts from O. basilicum, O. canum and $O$. gratissimum with rosmarinic acid, luteolin and vitexin as standards; developed with Methylene Dichloride/ acetone/formic acid 85:25:8.5 and visualized at $365 \mathrm{~nm}$ with Natural Products-PEG reagent.

fluorescent spots); chromatogram (b): phenols acids RA.

The presence of RA was confirmed by HPLC fingerprint of control pure RA in superimposing this last to the fingerprint of each methanolic extract of the three Ocimum.

\subsection{High Performance Liquid Chromatography (HPLC) Analysis}

Figure 2 shows the structure and the HPLC fingerprint of pure RA used as control by reason of comparison to the three HPLC fingerprints of the three methanolic extracts of three Ocimum.

As it can be clearly seen, the pure RA (a) appears as a single peak to the retention time equal to 32.408 minutes. As above noticed the profile of methanolic extract of $O$. canum (b) shows two intense peaks. The most intense and consequently major compound appears to the retention time equal to 58.719 minutes, followed by the one at 32.494 minutes. This last has approximately equal RA retention time. These results are near to what found by Berhow et al. [35] who has found a retention time of $30.07 \mathrm{~min}$.

The presence of RA in the methanolic extract of $O$. canum is confirmed by the overlay of both the pure RA peak and the characterized fingerprint of methanolic extract, at the same retention time. The available data in the database used as references of the system did not allow us to identify the compound to the retention time of 58.719 minutes.

It can also be seen in the fingerprint of $O$. basilicum (b) the most intense peak to the retention time of 32.300 min. Approximately this last value is equal to the one above of RA. These results are alike to that of Vlase et al. [36] in methanolic extract of $O$. basilicum from Romania.

The presence of RA is demonstrated by the superimposition of the peak of the HPLC fingerprint of pure rosmarinic acid with the corresponding peak of the HPLC fingerprint of the methanolic extract of $O$. basilicum, to the identical retention time. By comparing the two intensities identified above peaks between $O$. canum and $O$. $b a-$ silicum, the peak of this last (b) appears to be more intense. Thus, that result confirms that $O$. basilicum has more important amount of RA than $O$. canum.

Ultimately, it is noticed in Figure 2 in the fingerprint of $O$. gratissimum (d) the most intense peak to the retention time of $32.310 \mathrm{~min}$. This seems to be approximately to RA founded value. This result is comparable to that found by Costa et al. [37] in methanolic extract of O. gratissimum from Brazil.

As for the two first methanolic extracts, the presence of RA is shown by the overlay of the two peaks of pure RA and the one of the methanolic extract of $O$. gratissimum to the almost equal time of retention. Once more 

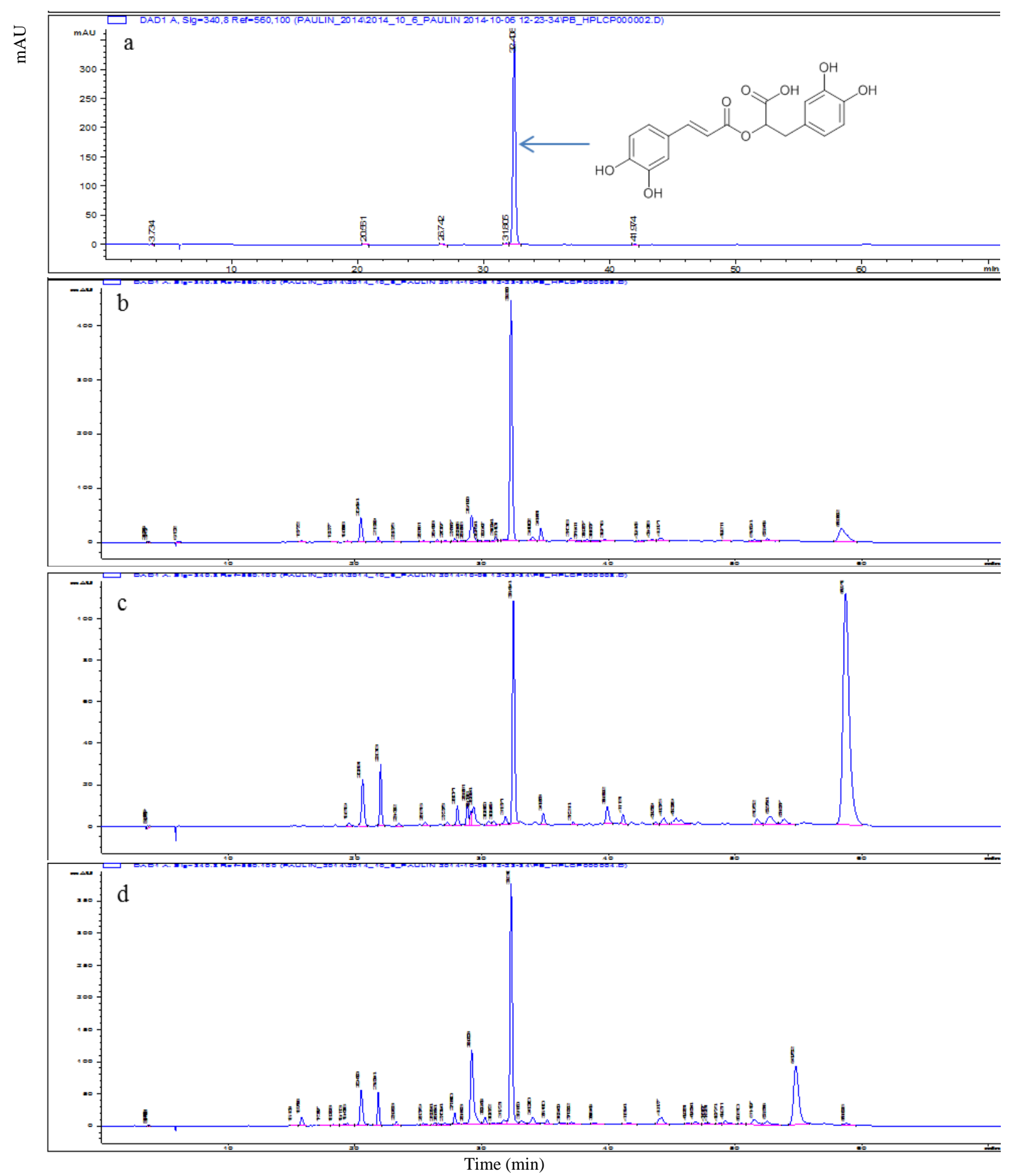

Figure 2. HPLC-DAD chromatograms of Rosmarinic acid (a) and methanolic extracts from O. basilicum (b), O.canum (c), O. gratissimum (d) using a nonlinear gradient of acetonitril (A) and $0.05 \%$ trifluoroacetic acid in ultra pure water (B): 0 min, 0:100 (A:B), $1 \mathrm{~min}, 3: 97(\mathrm{~A}: \mathrm{B}) ; 45 \mathrm{~min}, 40: 60$ (A:B); 46min, 0:100 (A:B) and $60 \mathrm{~min}$, stop at $1 \mathrm{~mL} / \mathrm{min}$ on Hypersil ODS column $(4 \mathrm{~mm} \times 250 \mathrm{~mm})$ with detection at $340 \mathrm{~nm}$. The elution time is given in minutes (horizontal axis). On the $y$ axis, the height of the elution peak, expressed in arbitrary milli-unities (mAU) corresponds to the concentration of the eluted compound in the sample analysed.

again comparing the three fingerprints of the methanolic extracts of the three species according to their intensity, $O$. basilicum contains the highest amount of RA, followed by O. gratissimum and then $O$. canum. 


\subsection{Antisickling Activity}

Figures 3(a)-(f) show respectively micrographies of SS blood alone in a $\mathrm{NaCl} 0.9 \%$ solution (negative control), betulinic acid (positive control) and the sickle cells blood incubated with the methanolic extract of $O$. canum, $O$. gratissimum and $O$. basilicum, and RA finally.

As it can be seen from these micrographies, the negative control (Figure 3(a)) contains the majority of sickleshaped erythrocytes, confirming the Sickle cell nature of the blood. When betulinic acid, well known for its antisickling activity [17] [18] [38], is added as positive control (Figure 3(b)), Red blood cells show their normal circular (biconcave) shape. In the presence methanolic extracts of the three species of Ocimum (Figures 3(c)-(e))

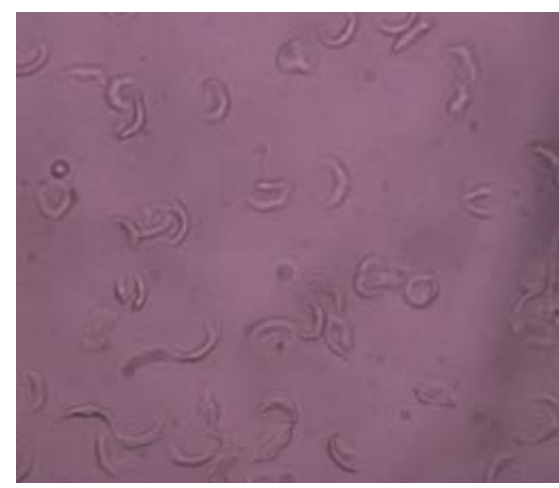

(a)

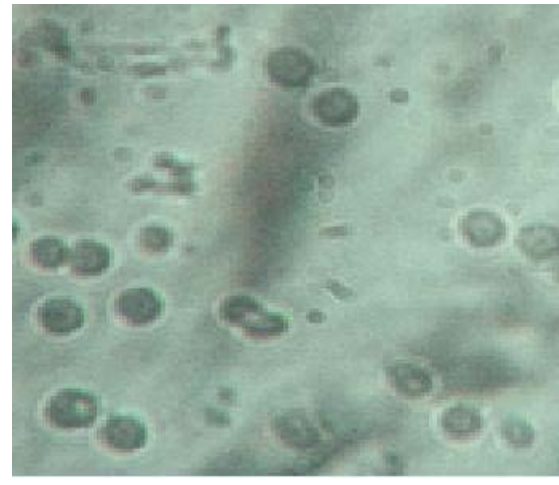

(c)

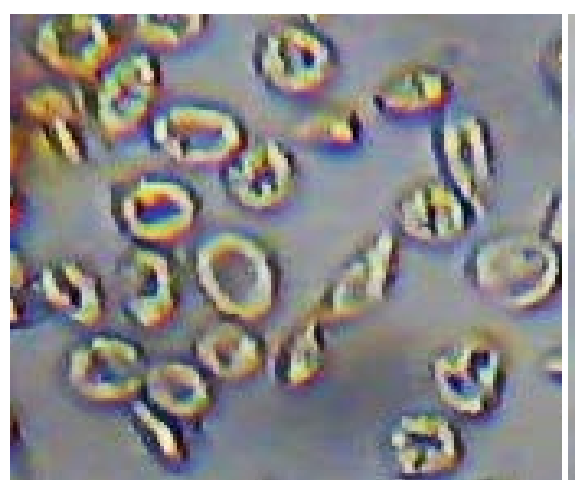

(e)

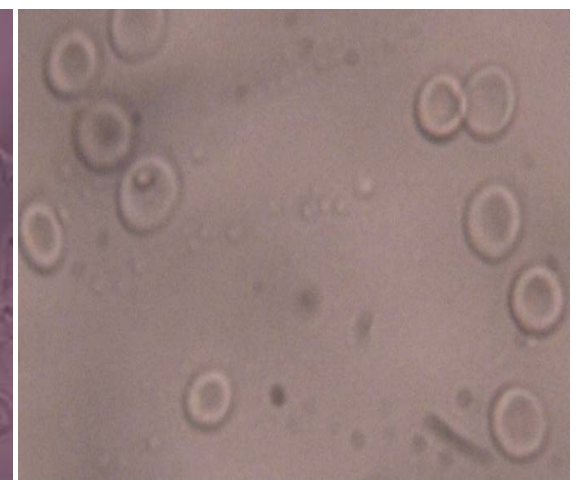

(b)

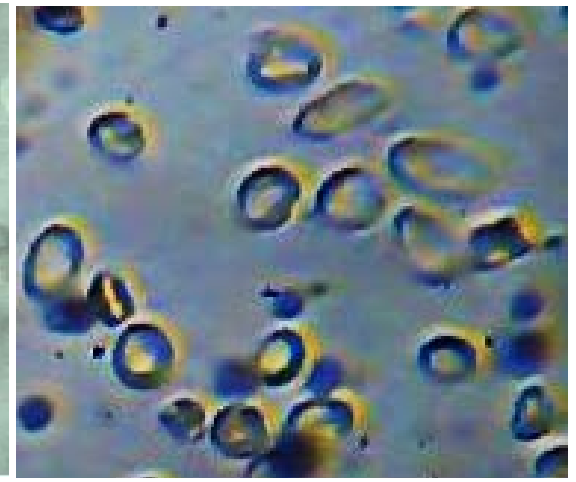

(d)

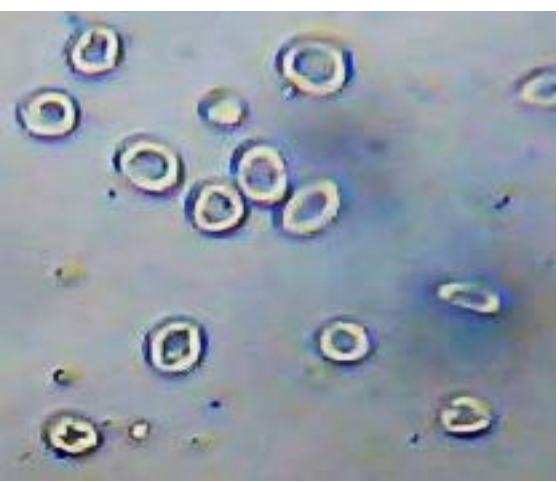

(f)

Figure 3. Morphology of erythrocytes of untreated SS blood (negative control, a); treated with $20 \mu \mathrm{g} / \mathrm{mL}$ of betulinic acid (positive control, b); treated with $40 \mu \mathrm{g} / \mathrm{mL}$ of methanolic extract of $O$. canum (c); treated with $40 \mu \mathrm{g} / \mathrm{mL}$ of $O$. gratissimum (d); treated with $40 \mu \mathrm{g} / \mathrm{mL}$ of $O$. basilicum (e); treated with $20 \mu \mathrm{g} / \mathrm{mL}$ of pure rosmarinic acid solution (f) $\left[\mathrm{NaCl} 0.9 \% ; \mathrm{Na}_{2} \mathrm{~S}_{2} \mathrm{O}_{4} 2 \%\right.$; $\left.\times 500\right]$. 
and RA (Figure 3(f)), the majority of erythrocytes are reversed normal-shape. This fact indicates that the methanolic extracts have an antisickling activity and show also a good normalization effect of drepanocytes in hypoxic condition. The same behavior was already observed form active extracts from some plants used in the management of sickle disease in Congolese traditional medicine, justifying their traditional use. Some molecules contained in these extracts would interact with $\mathrm{HbS}$ and compete with its polymerization reaction. This would prevent the sickling of red blood cells. In fact, according to Russu et al. [39] when investigating on molecular basis for the antisickling activity of aromatic amino acids and related compounds by NMR, phenolic acids would interact with $\mathrm{HbS}$ on a binding site located at or near the beta 6 position (the site containing the mutation in beta 6Glu to Val). This binding would induce conformational changes in the amino-terminal domains of the beta chains.

\subsection{Normalization Rate}

To compare the antisickling activity of different drugs, it is necessary to determine the minimal concentration of normalization (MCN) or the concentration that normalizes 50\% of drepanocytes (ED50) [5] [9] [10] [15] [16].

Figure 4 gives the dose dependent antisickling activity of methanolic extracts of three Ocimum leaves and RA.

Figure 4 shows that the sickle cells normalization rate increases with the methanolic extracts doses until reaching the maximum threshold of which the normalization rate remains constant despite the increase of the extracts concentration. The determined minimal concentrations of normalization of each extract and RA i.e. the weakest concentration of extracts or RA for which the normalization rate is maximum are listed in the table.

As it can be noticed from Table 1, RA shows higher antisickling effect than all methanolic extracts. This indicates that the main secondary metabolites responsible of the antisikling effect in the three methanolic extracts have to be found as RA. This is confirmed by the fact that $O$. basilicum has highest amount of RA and exhibited
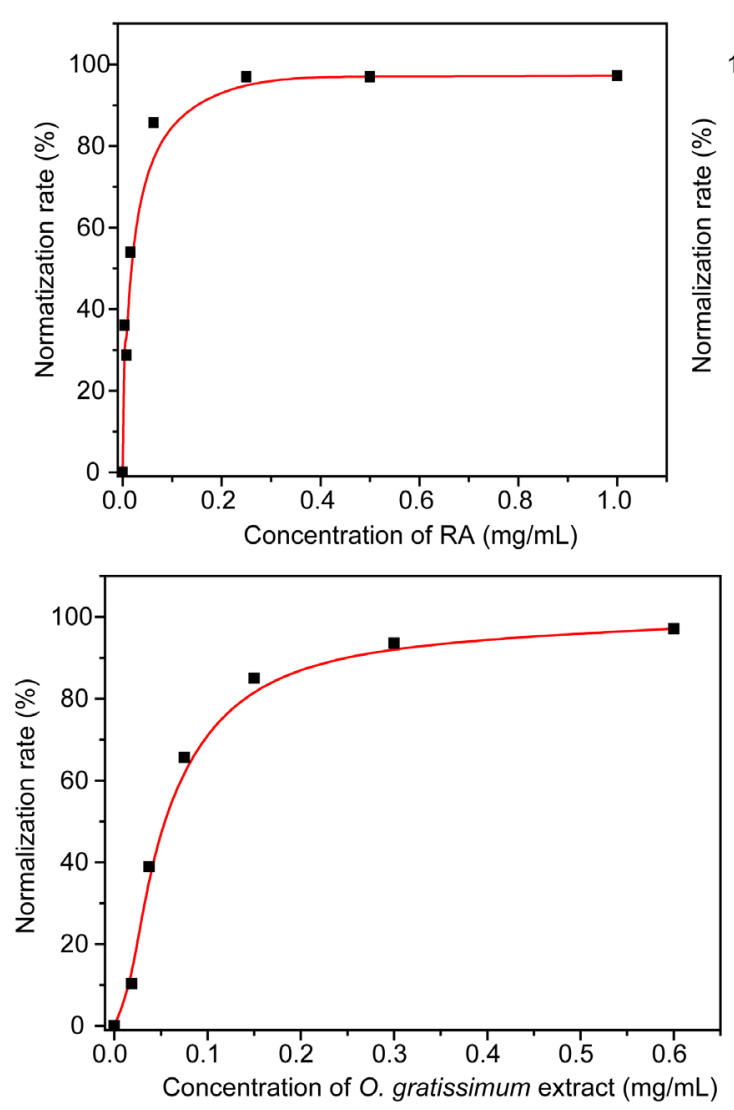
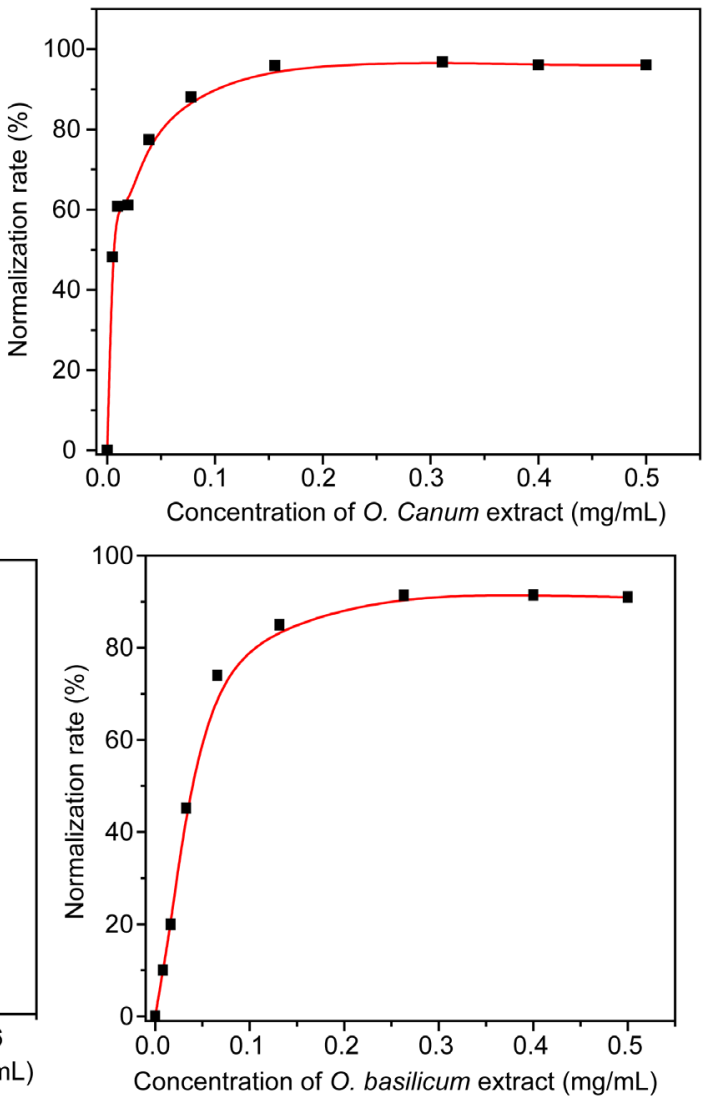

Figure 4. Evolution of the normalization rate of the drepanocytes form with the methanolic extracts of Ocimum and rosmarinic acid (RA). 
Table 1. Minimal concentration of normalization (MCN) of different methanolic extracts and rosmarinic acid.

\begin{tabular}{cc}
\hline SAMPLES & MCN $(\mathbf{m g} / \mathbf{m L})$ \\
\hline Rosmarinic acid & $0.18 \pm 0.03$ \\
Ocimum basilicum & $0.23 \pm 0.04$ \\
Ocimum gratissimum & $0.26 \pm 0.04$ \\
Ocimumcanum & $0.31 \pm 0.05$ \\
\hline
\end{tabular}

the highest antisickling activity, follow by $O$. gratissimum and then $O$. canum. In fact, most isolated antisickling active molecules are phenolic acids [18] [38]-[41]. These results indicate that rosmarinic acid is among these antisickling active organic acids. The kwon antioxidant activity of RA [29] [35] [37] may also contribute to its antisickling activity, because sickle disease is in relation with the oxidative stress [42] [43].

\section{Conclusion}

The present study fingerprinted methanolic and tested the antisickling activity of extracts of three species of Ocimum from DR Congo: O. basilicum L., O. gratissimum L. and O. canum S. The TLC and HPLC analysis confirmed the presence of Flavonoids like kampferol derivates, phenolic acids and RA as phenol acid. This last is in high amount in the three Ocimum species extracts. The $O$. basilicum specie has a higher quantity of RA acid, followed by $O$. gratissimum and then $O$. canum. This order is also respected for the antisickling activity since pure RA has the highest antisickling activity and would be among the phenolic acids responsible of antisickling activity of these Ocimum species. RA could constitute a phyto-marker for the quality control of herbal medicines from these three plants without its isolation as pure compound.

\section{Acknowledgements}

One of the authors ( Prof. Pius T. Mpiana) thanks The World Academy of Sciences (TWAS) for the Research grant No. 15-156 RG/CHE/AF/AC_G_FR3240287018 and the "Académie de Recherche et d'Enseignement supérieur (ARES) du Royaume de Belgique” for the Research grant PAH-2015 ARES/UNIKIN.

\section{References}

[1] Buchanan, G.R., De Baun, M.R., Quinn, C.T. and Steinberg, M.H. (2004) Sickle Cell Disease. Hematology, 2004, 3547. http://dx.doi.org/10.1182/asheducation-2004.1.35

[2] Mehanna, A.S. (2001) Sickle Cell Anaemia and Antisickling Agents Then and Now. Current Medicinal Chemistry, 8, 79-88. http://dx.doi.org/10.2174/0929867013373778

[3] Mpiana, P.T., Lombe, B.K., Mahano, A.O., Ngbolua, K.N., Tshibangu, D.S.T., Wimba, L.K., Tshilanda, D.D., Mushangalusa, F.K. and Muyisa, S.K. (2013) In Vitro Sickling Inhibitory Effects and Anti-Sickle Erythrocytes Hemolysis of Dicliptera colorata C. B. Clarke, Euphorbia hirta L. and Sorghum bicolor (L.) Moench. Open Journal of Blood Disease, 3, 43-48. http://dx.doi.org/10.4236/ojbd.2013.31009

[4] Mpiana, P.T., Misakabu, F.M., Tshibangu, D.S.T., Ngbolua, K.N. and Mwanangombo, D.T. (2014) Antisickling Activity and Membrane Stabilization Effect of Anthocyanins Extracts from Adansonia digitata L. Barks on Sickle Blood Cells. International Blood Research and Reviews, 2, 198-212.

[5] Ngbolua, K.N., Tshibangu, D.S.T., Mpiana, P.T., Mazasa, S.O., Mavakala, B.K., Ashande, M.C. and Muanishay, L.C. (2015) Anti-Sickling and Antibacterial Activities of Some Extracts from Gardenia ternifolia subsp. Jovis-Tonantis (Welw) Verdc (Rubiaceae) and Uapaca heudelotii Baill. (Phyllanthaceae). Journal of Advances in Medical and Pharmaceutical Sciences, 2, 10-19. http://dx.doi.org/10.9734/JAMPS/2015/13427

[6] Mahomoodally, F.M. (2013) Traditional Medicines in Africa: An Appraisal of Ten Potent African Medicinal Plants. Evidence-Based Complementary and Alternative Medicine, 2013, Article ID: 617459.

http://dx.doi.org/10.1155/2013/617459

[7] Mpiana, P.T., Tshibangu, D.S.T., Shetonde, O.M. and Ngbolua, K.N. (2007) In Vitro Anti-Drepanocytary Activity (Anti-Sickle Cell Anaemia) of Some Congolese Plants. Phytomedicine, 14, 192-195.

http://dx.doi.org/10.1016/j.phymed.2006.05.008 
[8] Mpiana, P.T., Mudogo, V., Ngbolua, K.N., Tshibangu, D.S.T., Shetonde, O.M. and Mbala, M.B. (2007) In Vitro Antisickling Activity of Anthocyanins from Ocimum basilicum L. (Lamiaceae). International Journal of Pharmacology, 3, 371-4

[9] Mpiana, P.T., Mudogo, V., Tshibangu, D.S.T., Ngbolua, K.N., Mangwala, P.K., Atibu, E.K., Kakule, M.K., Makelele, L.K. and Bokota, M.T. (2010) Antisickling Activity and Thermo degradation of an Anthocyanin fraction from Ocimum basilicum L. (Lamiaceae), In: Gupta, V.K., Ed., Composition and Bioactivity of Natural Products, Vol. 3: Effects, Safety \& Clinical Evaluation (Part II), Studium Press LLC, New York, 279-287.

[10] Mpiana, P.T., Makelele, L.K., Oleko, R.W., Bokota, M.T., Tshibangu, D.S.T., Ngbolua, K.N., Mbala, M.B., Atibu, E.K. and Nsimba, S.M. (2010) Antisickling Activity of Medicinal Plants Used in the Management of Sickle Cell Disease in Tshopo District, D.R. Congo. Australian Journal of Medical Herbalism, 22, 132-137.

[11] Mpiana, P.T., Ngbolua, K.N., Mudogo, V., Tshibangu, D.S.T., Atibu, E.K., Mbala, B.M., Kahumba, B., Bokota, M.T. and Makelele, L.T. (2012) The Potential Effectiveness of Medicinal Plants Used for the Treatment of Sickle Cell Disease in the Democratic Republic of Congo Folk Medicine: A Review. In: Gupta, V.K. and Singh, G.D., Eds., Traditional and Folk Herbal Medicine, Vol. 1, Daya Publishing House, New Delhi, 1-11.

[12] Ngbolua, K.N., Modogo, V., Mpiana, P.T., Malekani, M.J., Rafatro, H., Urverg Ratsimamanga, S., Takoy, L., Rakotoarimana, H. and Tshibangu, D.S.T. (2013) Evaluation de l'activité anti-drépanocytaire et antipaludique de quelques taxons végétaux de la République démocratique du Congo et de Madagascar. Ethnopharmacologia, 50, 7-12.

[13] Ngbolua, K.N., Mpiana, P.T., Tshibangu, D.S.T., Mazasa, P.P., Gbolo, B.Z., Atibu, E.K., Kadima, J.N. and Kasali, F.M. (2014) In Vitro Antisickling and Radical Scavenging Activities of a Poly-Herbal Formula (Drepanoalpha $\left.{ }^{\circledR}\right)$ in Sickle Cell Erythrocyte and Acute Toxicity Study in Wistar Albino Rats. European Journal of Medicinal Plants, 4, 1251-1267. http://dx.doi.org/10.9734/EJMP/2014/11861

[14] Ngbolua, K.T.N., Bishola, T.T., Mpiana, P.T., Mudogo, V., Tshibangu, D.S.T., Ngombe, K.N., Ekutsu, E.G., Tshilanda, D.D., Gbolo, B.Z., Mwanangombo, D.T., Ruphin, F.P. and Baholy, R. (2014) Ethno-Botanical Survey, in Vitro Antisickling and Free Radical Scavenging Activities of Garcinia punctata Oliv. (Clusiaceae). Journal of Advanced Botany and Zoology, 2, 1-8.

[15] Ngbolua, K.T.N., Bishola, T.T., Mpiana, P.T., Mudogo, V., Tshibangu, D.S.T., Ngombe, K.N., Ekutsu, E.G., Gbolo, B.Z. and Ngandu, O.K. (2014) Ethno-Pharmacological Survey, in Vitro Anti-Sickling and Free Radical Scavenging Activities of Carapa procera DC. Stem Bark (Meliaceae). Nova Journal of Medical and Biological Sciences, 2, 1-14.

[16] Mpiana, P.T., Mudogo, V., Tshibangu, D.S.T., Kitwa, E.K., Kanangila, A.B., Lumbu, J.B.S., Ngbolua, K.N., Atibu, E.K. and Kakule, M.K. (2008) Antisickling Activity of Anthocyanins from Bombax pentadrum, Ficus capensisanv Ziziphus mucronata: Photodegradation Effect. Journal of Ethnopharmacology, 120, 413-418. http://dx.doi.org/10.1016/j.jep.2008.09.012

[17] Tshilanda, D.D., Mpiana, P.T., Onyamboko, D.N.V., Mbala, B.M., Ngbolua, K.N., Tshibangu, D.S.T., Bokolo, M.K., Taba, K.M. and Kasonga, T.K. (2014) Antisickling Activity of Butyl Stearate Isolated from Ocimum basilicum (Lamiaceae). Asian Pacific Journal of Tropical Biomedicine, 4, 393-398. http://dx.doi.org/10.12980/APJTB.4.2014C1329

[18] Tshilanda, D.D., Onyamboko, D.N.V., Babady-Bila, P., Ngbolua, K.N., Tshibangu, D.S.T., Dibwe, E.D.F. and Mpiana, P.T. (2015) Anti-Sickling Activity of Ursolic Acid Isolated from the Leaves of Ocimum gratissimum L. (Lamiaceae). Natural Products and Bioprospecting, 5, 215-221.

[19] Tshilanda, D.D., Onyamboko, D.V., Mwanangombo, D.T., Tsalu, P.V., Misengabu, N.K., Tshibangu, D.S.T., Ngbolua, K.N. and Mpiana, P.T. (2015) In Vitro Antisickling Activity of Anthocyanins from Ocimum canun (Lamiacea). Journal of Advancement in Medical and Life Sciences, 3.

[20] Tshilanda, D.D., Onyamboko, D.V., Tshibangu, D.S.T., Ngbolua, K.N., Tsalu, P.V. and Mpiana, P.T. (2015) In Vitro Antioxidant Activity of Essential Oil and Polar and Non-Polar Extracts of Ocimum canum from Mbuji-Mayi (DR Congo). Journal of Advancement in Medical and Life Sciences, 3.

[21] Adesina, S.K. (2005) The Nigerian Zanthoxylum; Chemical and Biological Values. African Journal of Traditional, Complementary, and Alternative Medicines, 2, 282-301.

[22] Vieira, R.F., Grayer, R.J. and Paton, A.J. (2003) Chemical Profiling of Ocimum americanum Using External Flavonoids. Phytochemistry, 63, 555-567. http://dx.doi.org/10.1016/S0031-9422(03)00143-2

[23] Kaurinovic, B., Popovic, M., Vlaisavljevic, S. and Trivic, S. (2011) Antioxidant Capacity of Ocimum basilicum L. and Origanum vulgare L. Extracts. Molecules, 16, 7401-7414. http://dx.doi.org/10.3390/molecules16097401

[24] Mbakwem-Aniebo, C., Onianwa, O. and Okonko, I.O. (2012) Effects of Ocimum gratissimum Leaves on Common Dermatophytes and Causative Agent of Pityriasis Versicolor in Rivers State, Nigeria. Journal of Microbiology Research, 2, 108-113. http://dx.doi.org/10.5923/j.microbiology.20120204.08

[25] Vyry Wouatsa, N.A., Misra, L. and Venkatesh Kumar, R. (2014) Antibacterial Activity of Essential Oils of Edible 
Spices, Ocimum canum and Xylopia aethiopica. Journal of Food Science, 79, M972-M977. http://dx.doi.org/10.1111/1750-3841.12457

[26] Kalita, J. and Latif Khan, M. (2013) Commercial Potentialities of Essential Oil of Ocimum Members Growing in North East India. International Journal of Pharmaceutical and Life Sciences, 4, 2559-2567.

[27] Matasyoh, J.C., Bendera, M.M., Ogendo, J.O., Omollo, E.O. and Deng, A.L. (2006) Volatile Leaf Oil Constituents of Ocimum americanum L. Occuring in Western Kenya. Bulletin of the Chemical Society of Ethiopia, 20, 177-180.

[28] Ntonga, P.A., Baldovini, N., Mouray, E., Mambu, L., Belong, P. and Grellier, P. (2014) Activity of Ocimum basilicum, Ocimum canum, and Cymbopogon citratus Essential Oils against Plasmodium falciparum and Mature-Stage Larvae of Anopheles funestuss s.s. Parasite, 21, 33. http://dx.doi.org/10.1051/parasite/2014033

[29] Al-Dhabi, N.A., Arasu, M.V., Park, C.H. and Park, S.U. (2014) Recent Studies on Rosmarinic Acid and Its Biological and Pharmacological Activities. EXCLI Journal, 13, 1192-1195.

[30] Ozturk, H., Ozturk, H., Terzi, E.H., Ozgen, U., Duran, A. and Uygun, I. (2014) Protective Effects of Rosmarinic Acid against Renal Ischaemia/Reperfusion Injury in Rats. Journal of Pakistan Medical Association, 64, 260-265.

[31] Swarup, V., Ghosh, J., Ghosh, S., Saxena, A. and Basu, A. (2007) Antiviral and Anti-Inflammatory Effects of Rosmarinic Acid in an Experimental Murine Model of Japanese Encephalitis. Antimicrobial Agents and Chemotherapy, 51, 3367-3370. http://dx.doi.org/10.1128/AAC.00041-07

[32] Buck, M.H. (2011) The Nagoya Protocol on Access to Genetic Resources and the Fair and Equitable Sharing of Benefits Arising from Their Utilization to the Convention on Biological Diversity. Review of European Community \& International Environment Law, 20, 47-61. http://dx.doi.org/10.1111/j.1467-9388.2011.00703.x

[33] Tsumbu, C.N., Deby-Dupont, G., Tits, M., Angenot, L., Franck, T., Serteyn, D. and Mouithys-Mickalad, A. (2011) Antioxidant and Antiradical Activities of Manihot esculenta Crantz (Euphorbiaceae) Leaves and Other Selected Tropical Green Vegetables Investigated on Lipoperoxidation and Phorbol-12-myristate-13-acetate (PMA) Activated Monocytes. Nutrients, 3, 818-838. http://dx.doi.org/10.3390/nu3090818

[34] Wagner, H. and Bladt, S. (1996) Plant Drug Analysis: A Thin Layer Chromatography Atlas. 2nd Edition, Springer-Verlag, Berlin. http://dx.doi.org/10.1007/978-3-642-00574-9

[35] Berhow, M.A., Obeng Affum, A. and Gyan, B.A. (2012) Rosmarinic Acid Content in Antidiabetic Aqueous Extract of Ocimum canum Sims Grown in Ghana. Journal of Medicinal Food, 15, 611-620. http://dx.doi.org/10.1089/jmf.2011.0278

[36] Vlase, L., Benedec, D., Hanganu, D., Damian, G., Csillag, I., Sevastre, B., Mot, A.C., Silaghi-Dumitrescu, R. and Tilea, I. (2014) Evaluation of Antioxidant and Antimicrobial Activities and Phenolic Profile for Hyssopus officinalis, Ocimum basilicum and Teucrium chamaedrys. Molecules, 19, 5490-5507. http://dx.doi.org/10.3390/molecules19055490

[37] Costa, R.S., Brasil Carneiro, T.C., Cerqueira-Lima, A.T., Queiroz, N.V., Alcântara-Neves, N.M., Pontes-de-Carvalho, L.C., Velozo, E.S., Oliveira, E.J. and Figueiredo, C.A. (2012) Ocimum gratissimum Linn. and Rosmarinic Acid, Attenuate Eosinophilic Airway Inflammation in an Experimental Model of Respiratory Allergy to Blomia tropicalis. International Immunopharmacology, 13, 126-134. http://dx.doi.org/10.1016/j.intimp.2012.03.012

[38] Shode, F.O., Koorbanally, N., Mpiana, P.T., Tshibangu, D.S.T., Oyedeji, O.O., Habila J.D. and University of KwaZulu Natal (2011) In Vitro Anti-Sickling Activity of Betulinic Acid, Oleanolic Acid and Their Derivatives. World International Property Organisation WIPO, Patent No. WO2011/064710 A1. http://www.google.com/patents/WO2011064710A1?cl=en

[39] Russu, I.M., Lin, A.K., Yang, C.P. and Ho, C. (1986) Molecular Basis for the Anti-Sickling Activity of Aromatic Aminoacids and Related Compounds: A Proton Nuclear Magnetic Resonance. Biochemistry, 25, 808-815. http://dx.doi.org/10.1021/bi00352a012

[40] Gorecki, M., Acquaye, C.T., Wilchek, M., Votano, J.R. and Rich, A. (1980) Antisickiling Activity of Amino Acidbenzyl Esters. Proceedings of the National Academy of Sciences of the United States of America, 77, 181-185. http://dx.doi.org/10.1073/pnas.77.1.181

[41] Akoje, F.O. and Fung, L.W. (1992) Antisickling Activity of Hydroxybenzoic Acids in Cajanus cajan. Planta Medica, 58, 317-320. http://dx.doi.org/10.1055/s-2006-961475

[42] Silva, D.G.H., Junior, E.B., Almeida, E.A. and Bonini-Domingos, C.R. (2013) Oxidative Stress in Sickle Cell Disease: An Overview of Erythrocyte Redox Metabolism and Current Antioxidant Therapeutic Strategies. Free Radical Biology and Medicine, 65, 1101-1109. http://dx.doi.org/10.1016/j.freeradbiomed.2013.08.181

[43] Junior, E.B., Silva, D.G.H., Torres, L.S., Almeida, E.A., Cancado, R.D., Chiattone, C. and Bonini-Domingos, C.R. (2012) Oxidative Stress and Antioxidant Capacity in Sickle Cell Anaemia Patients Receiving Different Treatments and Medications for Different Periods of Time. Annals of Hematology, 91, 479-489.

http://dx.doi.org/10.1007/s00277-011-1340-y 